\title{
Evaluating Position of Bangladesh to Combat 'Adulterated Food' Crisis in Light of Human Rights
}

\author{
Mirza Farzana Iqbal Chowdhury \\ (Lecturer, Department of Law, Daffodil International University, Bangladesh)
}

\begin{abstract}
Right to food is one of the human rights to which people are entitled simply by virtue of being born as human beings. Though in the context of Bangladesh, 'Right to food' is only one of 'Directive Principles of State Policy' which is unenforceable in nature, but in this paper I tried to link this right with other enforceable human rights so that State cannot neglect or refuge to implement this very right. There are various dimensions of 'Right to Food' and food adulteration is one of them. Food adulteration has now become a major threat to public health and because of adulterated food people are suffering various types of health problems. In this paper I tried to sort out the approach of the government to deal with this issue and examined the efficiencies of stake-holders. I tried to sort out challenges and prospects of this issue and suggested recommendations. Lastly I concluded emphasizing on changing of approach of government by considering inclusion of the 'Right to Food' in the broader term of 'Right to life' to make this rhetoric right into a real and enforceable right. I adopted qualitative approach and used secondary sources, i.e. newspaper, articles, seminar proceedings, websites etc.
\end{abstract}

Keywords: Adulterated foods, Bangladesh, Human rights, Implementation, Right to food, Right to life.

\section{Introduction}

'Human Rights' are the most crucial rights of human being which are violated every day all over the world. Human rights are those entitlements which people acquire simply by birth irrespective of their identity. 'Right to Food' is one of the human rights specially categorized as 'Economic, Social and Cultural Rights'. Its recognition as a human right and inter-relation with other human rights have been reiterated in various international instruments, i.e. the Universal Declaration of Human Rights (UDHR); the International Covenant on Economic, Social and Cultural Rights (ICESCR); the Convention on the Elimination of All Forms of Discrimination Against Women (CEDAW); and the Convention on the Rights of the Child (CRC).

To respect, protect and fulfill human rights is the obligation of governments and other stake-holders responsible for ensuring human rights. Human rights have individual and collective aspects which need to be recognized by States and these are enshrined in their constitutions in various format and in international law. Proper functioning of human rights protection system requires i. ratification of the relevant human rights treaties and their constitutional protection, ii. enactment of appropriate legislation and iii.further implementation.

In the context of 'Right to food' we find that Bangladesh ratified relevant human rights treaties and in the Constitution of Bangladesh, right to food is not directly addressed and included in the article.15 titled 'Basic Necessities of Life' which is a directive principle of State policy only. Now the question comes whether Bangladesh can be compelled to implement its human rights guarantees as Bangladesh ratified all important human rights instruments or whether ensuring 'Right to food' is only a rhetoric which cannot be implemented by State excuse of poor economy and its status as an aim or goal only. My paper focuses on the importance of adopting the first approach by Bangladesh and stake-holders for combating adulterated food crisis.

The objectives of this paper are as follows:

\section{Objectives}

1. To focus on linkage between 'Right to food' and other human rights which are categorized as fundamental rights in the constitution of Bangladesh.

2. To sort out the approach of the government to deal with this issue.

3. To examine the efficiencies of stake-holders.

4. To sort out challenges and prospects of this issue.

5. To suggest recommendations emphasizing on changing of approach of government by considering inclusion of the 'Right to Food' in the broader term of 'Right to life' to make this rhetoric right into a real and enforceable right. 


\section{Methodology}

I adopted qualitative approach to justify this paper and for that purpose data were collected from various secondary sources, i.e. newspaper, articles, seminar proceedings, websites etc. and processed.

\section{Defining Adulterated Food}

Adulterated food in its general sense means impure, unsafe or unwholesome food.If a food is mixed with a constituent which is non-nutritive shall be deemed to be adulterated.If the poisonous substance is naturally present in a food in an amount not ordinarily making the food harmful for health, the food will not be deemed as adulterated'(Wikipedia, 2013).

The meaning of adulteration varies from country to country on the basis of municipal law. If a food exceeds tolerances and regulatory limits of the country, it will be considered adulterated. If a food contains a poisonous substance in excess of municipal tolerance and regulatory limits, or if it is mixed with "clean" food, it renders the whole food adulterated (ibid). Again "food is adulterated if it omits a valuable nutritive constituent or substitutes a non-nutritive substance wholly or partly, for a valuable constituent, conceals damage or inferiority of food such as fresh fruit with food coloring and wax on its surface; or if any substance was added to it or packed with it to increase its bulk or weight, reduce its quality or strength, or make it appear bigger or of greater value than it is' (Wikipedia, 2013).

Under Bangladeshi laws, though the term 'Adulteration of food' is used but it is not specifically defined anywhere. By the practices, food adulteration in Bangladesh means adding harmful chemicals, toxic colors or harmful additives with the food.

\section{Adulterated Foods And Bangladesh}

\subsection{International Commitments of Bangladesh}

Bangladesh ratified various international instruments, i.e. the Universal Declaration of Human Rights (UDHR) 1948; the International Covenant on Economic, Social and Cultural Rights (ICESCR) 1966; the Convention on the Elimination of All Forms of Discrimination against Women (CEDAW) 1989; and the Convention on the Rights of the Child (CRC) 1990 where right to food is guaranteed. Right to food is directly related to ICESCR as it is one of the economic, social and cultural rights and Bangladesh ratified this covenant on 5 October, 1998 (Golay and Ozden, n.d.).

\subsection{Constitutional Stand}

Article 15 of the Constitution of Bangladesh provides basis for right to food under the title 'Provision of basic necessities' which speaks that 'It shall be a fundamental responsibility of the State to attain, through planned economic growth, a constant increase of productive forces and a steady improvement in the material and cultural standard of living of the people, with a view to securing to its citizens-(a) the provision of the basic necessities of life, including food, clothing, shelter, education and medical care' (Bangladesh Constitution, 1972). Article 18 of the Constitution speaks that 'The state shall raise the level of nutrition and improve public health as its primary duties'. Both the articles imply food safety requirements for consumers.

In a research, it is found that thirteen countries explicitly recognize the right to food within the constitution as a directive principle or goal and Bangladesh is one of them (Wikipedia, 2013). So although, right to food is articulated in the constitution of Bangladesh, it was not given the status of 'Fundamental right' which is enforceable under article 44 of the constitution.

\subsection{Present Scenario of Adulterated Foods in Bangladesh}

Food safety has become a matter of great concern in Bangladesh as it is much-reported that consumers in Bangladesh are being victimized by serious adulteration in food (Tiwari, n.d.). These adulterations are seriously injurious to public health. Most of the food-stuffs in Bangladesh are unsafe for consumption as from production to consumption such as, food manufacturers, processors, restaurants, fast food outlets and so forth, all are involved in this chain of adulteration. Adulteration of Food is occurring by using various harmful chemicals, toxic artificial colors or additives. Unhygienic and unsafe treatment of food also renders the food adulterated (Ali, 2013). Adulterations get its peak in Ramadan time in order to earn quick and huge profit. It is reported that 'among all adulterations, grave concerns exist on over-flooding of the local markets with adulterated and chemical poison-mixed baby foods, vegetables, fish, meat, fruits, hotel and packed foods, adulterated and date expired life-saving medicines' (Ahmed, 2013). Government officials also expressed their grave concern over the matter in various seminars (Alam, 2013).

In a discussion on hazards of food contamination in national life "Way Forward" held at the Daily Star center in Dhaka, S K Roy, scientist at the International Centre for Diarrhoeal Diseases Research, Bangladesh (ICDDR, B) presented that more than 76 percent food items on the market were found adulterated in a random 
survey conducted by the Public Health Laboratory of Dhaka City Corporation in 2004 (Rahman, 2013). A table is prepared in light of his presentation (ibid)-

Table-1: Adulteration of Foods

\begin{tabular}{|l|l|}
\hline Additives & Applying area \\
\hline Formalin & $\begin{array}{l}\text { Fish for preservation, fruit, milk, } \\
\text { meat }\end{array}$ \\
\hline Calcium carbide & Fruits to ripen \\
\hline Brick-dust & Chili powder \\
\hline Urea & Whiten rice and puffed rice \\
\hline Saw dust & Loose tea \\
\hline Soap & Ghee \\
\hline Artificial sweetener, coaltar and textile dyes & Sweetmeats \\
\hline
\end{tabular}

If we just check some statistics relating to adulterated food, we will be able to understand how crucial the concern is!

The following statistics are collected from various newspapers, reports, websites which reveal the magnitude of adulterated foods and their adverse effects on health of people of Bangladesh and necessitate adoption of urgent initiatives by Government and other stake-holders.

- Referring the data of International Centre for Diarrhoeal Disease Research, Bangladesh (ICDDRB), World Health Organization (WHO) expressed that in Bangladesh at least 501 people visits hospital every day for diarrhoeal diseases that are related to food safety (Ali, 2013).

- Unhygienic processing of food has negative impact on export facilities in Bangladesh. In 1997 European Union banned importing shrimp from Bangladesh due to the lack of maintaining proper hygiene standards in the shrimp processing plants (ibid).

- World Health Organization expressed that, 150,000 children die each year in Bangladesh within first 4 weeks of their lives possibly due to DDT consumption by in-taking dried fish by pregnant mother (ibid).

- The Institute of Public Health (IPH) in Dhaka and the World Health Organization (WHO) in their joint study of 1994 on food adulteration tested 52 street vendors and found that, all of the vendors' food samples were contaminated with different types of disease breeding micro-organisms (ibid).

- The Institute of Public Health (IPH) in Dhaka and the World Health Organization (WHO) in their another joint study of 2003 conducted in the capital city revealed that 96 per cent of 400 sweetmeats, 24 per cent of 250 biscuits, 54 per cent of 50 breads, and 59 per cent of 200 ice creamsamples were adulterated and also found that over the preceding decades, some 50 percent of the food samples tested in IPH laboratory were adulterated (ibid).

- The doctors at Bumrungrad Hospital of Thailand established a close link between the rising number of patients for treatment of liver and kidney diseases or fertility problems with their consumption of various adulterated foods in Bangladesh. It is also noted in neighboring India and Singapore and investigative reports may well link the increasing number of abroad-going patients to food related causes. Doctors at Bumrungrad observed that if conditions do not improve in Bangladesh in relation to catering of healthy foods, then by 2020, the number of imbecile and disabled children will rise alarmingly' (Rasul, 2013)

- A seminar on public health reveals that every year 3 lakh people die of cancer, 50 thousand of diabetics and 2 lac people are attacked by kidney diseases due to intake of adulterated food (Rahman, 2013).

- The American Chemical Society (ACS), one of the world's largest scientific societies, has identified the presence of 0.01 to 0.3 parts per million ( $\mathrm{ppm}$ ) of cadmium per kilogram in Bangladeshi rice, which is beyond permissible levels. Maximum permissible level is $0.22 \mathrm{ppm}$ (Faruque, 2013). This finding is also supported by Bangladeshi scientists (ibid).

- Diarrhoeal diseases in Bangladesh still cause 5.7 million 'Disabilities Adjusted Life Years' which is $61 \%$ of total DALYs (Disability Adjusted Life Years) (FAO/WHO, 2004)

- Hygiene related diseases in Bangladesh costs US \$ 80 million each year for treatment alone (ibid).

\subsection{Effects of Adulterated Food on Public Health}

Adulterated foods pose a serious threat to public health. In a developing country like Bangladesh, where low per capita income, illiteracy, poor health literacy exist, this threat becomes more evident. The effects of consumption of adulterated foods may be either immediate or long-term or both. Immediate effects include food poisoning (diarrhoea) and consequently dehydration. The long-term effects may be organ failure such as the liver and kidney, causing cancer etc. Masud, S. (2012) claimed that 'There is no database in the country for 
these, but the recent surge in liver and kidney failure patients in the hospitals indicates the gravity of the deteriorating situation' (Ahmed, 2012).

The following table will give some light on adulterating elements and their harmful effects:

Table-2: Long-term Effects of Adulteration in Food

\begin{tabular}{|c|c|c|}
\hline Adulterating Element & $\begin{array}{l}\text { Appling area } \\
\text { of foods }\end{array}$ & Long-term effects \\
\hline $\begin{array}{l}\text { Colouring agents chrome, } \\
\text { tartzine and erythrosine } \\
\text { (Rahman, 2013) }\end{array}$ & $\begin{array}{l}\text { Spices, sauces, } \\
\text { juices, lentils } \\
\text { and oils }\end{array}$ & Cancer in kidney, liver, skin, prostate and lungs \\
\hline Rye flour (ibid) & $\begin{array}{l}\text { Barley, bread } \\
\text { and wheat flour }\end{array}$ & Convulsion and miscarriage \\
\hline Hormone (ibid) & Cauliflower & Infertility of women \\
\hline $\begin{array}{l}\text { Agenomato or } \\
\text { monosodium glutamate } \\
\text { (ibid) }\end{array}$ & $\begin{array}{l}\text { Chinese } \\
\text { restaurant food } \\
\text { items }\end{array}$ & Nervous system disorder and depression \\
\hline Urea (ibid) & $\begin{array}{l}\text { Puffed rice and } \\
\text { rice }\end{array}$ & Nervous system damage and respiratory problem \\
\hline Sulphuric acid (ibid) & Milk & Damage to the cardiac system \\
\hline $\begin{array}{l}\text { Oleomargarine or lard } \\
\text { (Ahmed, 2013) }\end{array}$ & Butter & Asthma and weakened kidney function \\
\hline $\begin{array}{l}\text { Yellow and Sudan Red } \\
\text { colours (ibid) }\end{array}$ & Chili powder & Tumours in liver and bladder and finally for cancer \\
\hline DDT (Ali, 2013) & $\begin{array}{l}\text { Dried fish } \\
\text { (shutki) }\end{array}$ & $\begin{array}{l}\text { a. Cancer especially breast cancer, liver cancer and } \\
\text { pancreatic cancer. } \\
\text { b. Productive issues i.e. unproductiveness, weaken } \\
\text { semen, abortion, early menopause, birth defects } \\
\text { and low birth weight of children. } \\
\text { c. Neurological issues on human health having } \\
\text { trembling, seizures, nausea and dizziness }\end{array}$ \\
\hline Formalin (Ali, 2013) & $\begin{array}{l}\text { Fish, fruit, meat } \\
\text { and milk }\end{array}$ & $\begin{array}{l}\text { Throat cancer, blood cancer, childhood asthma and } \\
\text { skin-diseases. }\end{array}$ \\
\hline $\begin{array}{l}\text { Poisonous colouring } \\
\text { agents like auramine, } \\
\text { rodomine b, malachile } \\
\text { green, yellow G, allura } \\
\text { red, and sudan red (The } \\
\text { Daily Star, 2013) }\end{array}$ & $\begin{array}{l}\text { Applied on food } \\
\text { items for } \\
\text { colouring, } \\
\text { brightness and } \\
\text { freshness }\end{array}$ & $\begin{array}{l}\text { Damage liver and kidney and cause stomach cancer, } \\
\text { asthma and bladder cancer }\end{array}$ \\
\hline
\end{tabular}

To combat adulterated food, an effective legal mechanism is necessary. We should evaluate the existing mechanism whether it is appropriate or not.

\subsection{Existing Legal Mechanism to Combat Adulterated Food}

There are several legislative enactments as well as ordinances to ensure the safety standard of food items and to punish the food adulterers e.g. the Bangladesh Pure Food Ordinance 1959 (repealed by new Safe Food Act, 2013); Bangladesh Pure Food Rules 1967; Food Grain Supply Ordinance 1956, the Radiation Protection Act, 1987; the Essential Commodity Act, 1990; Fish and Fish Product (Inspection and Quality Control) Rules, 1997 etc. These mentioned laws are expected to be coordinated by passing of the Safe Food Act, 2013. It is alleged that most of the provisions under the Pure Food Ordinance 1959, could not be effective tilldate (Rahman, 2013).

\subsubsection{Safe Food Act, 2013}

Safe Food Act, 2013 is approved by the cabinet on September 9, 2013 to replace the Bangladesh Pure Food Ordinance, 1959. Under this new Act, it has been proposed to constitute a National Food Safety Council (NFSC), headed by the Ministry of Health and Family Welfare as well as to establish food courts (Hossain, 2013). Under this approved Act, there is a provision of maximum five years' imprisonment or a fine of Taka 10 lakh or both for persons guilty of food adulteration and this amount of the fine will be doubled in case of repeating offence. The Safe Food Act also has a provision for setting up of a unified authority, Bangladesh Food Safety Authority (BFSA) modeled on the American Food and Drug Administration and comprising a chairman 
and five members to fight food adulteration and attend to other food-related concerns of consumers (The Daily Star, 2013).This authority (BFSA) will draw resources from all 15 ministries entrusted with combating food adulteration. But how BFSA will coordinate activities with other ministries and the Bangladesh Standards and Testing Institution (BSTI) has not been spelt out precisely (The Daily Star, 2013).It proposed forming as many food courts as deemed necessary to prosecute adulterators. The formation of a National Pure Food Management Advisory Council was proposed which will be headed by the food minister and consisting of members from different ministries and government, private and academic organizations. Complainants against food adulteration will be rewarded with one-fourth the amount of fine to be imposed on adulterators (The Daily Star, 2013).

\subsubsection{Other Laws and Regulations:}

In addition, a number of other laws and regulations exist in the country to ensure the safe and quality food viz. 'The Animal Slaughter (Restriction) and Meat Control (Amendment) Ordinance, 1983; the Pesticide Ordinance, 1971 and the Pesticides Rules, 1985; Destructive Insects and Pests Rules (Plant Quarantine), 1966, amended up to 1989; Agricultural Products Market Act, 1950 (revised in 1985); Fish Protection and Conservation Act, 1950 (amended in 1995);Marine Fisheries Ordinance 1983 and Rules, 1983; Procurement Specifications, Ministry of Food, Rice Mill Control Order' (Hossain, 2013), Food (Special Courts) Act 1956, Cantonments Pure Food Act 1966, The Breast-Milk Substitutes (Regulation of Marketing) Ordinance 1984, Consumer Rights Protection Act 2009, Local Government (City Corporation) Act 2009, Local Government Act, 2009, Mobile Court Act, 2009 (Ali, 2013),Bangladesh Standards and Testing Institution (BSTI) (Amendment) Act 2003 etc.

Within the framework of this BSTI Act, the task of BSTI is to certify the quality of commodities, materials, whether for local consumption or for export and import. Since its establishment, it is the sole body to look after the quality of the products in Bangladesh (ibid).

Furthermore, Ss.272, 273,274,275 and 276 of the Penal Code, 1860 (Act No. XLV of 1860) made adulteration of food or drink and sale of noxious food or drink punishable (Law Commission Bangladesh, 2013). Special Powers Act, 1974 also includes provisions in this regard. Mobile Courts has also jurisdiction by High Court order (The Daily Ittefaq, 2013).

\subsection{Enforcement Mechanism}

Bangladesh Food Safety Authority (BFSA) outlined in the approved Safe Food Act, 2013 is expected to replace the following stake-holders responsible for enforcement of food laws, rules and regulations: 'Ministry of Health and Family Welfare, Ministry of Law, Justice and Parliamentary Affairs, Ministry of Food and Disaster Management, Ministry of Industry, Ministry of Agriculture, Ministry of Environment and Forest, Ministry of Fisheries and Livestock, Ministry of Energy and Mineral Resources, Ministry of Commerce, Ministry of Defence (Tiwari, n.d.)', 'Ministry of Local Government, Rural Development and Co-operatives (MOLGRD), Ministry of Science, Information and Communication Technology, Ministry of Education, Ministry of Information, Ministry of Home Affairs (FAO/WHO, 2004).'

\subsection{Coordinating Mechanism}

'Cabinet is the only universal coordinating and controlling infrastructure. No single organization exists in Bangladesh to coordinate food control activities. There is also no structure of Food Safety Advisory Committee or Minimum Standard Fixing Committee' (ibid). Standard Wing of BSTI formulated about 365 food and agricultural product standards and services among those only 190 are food standards (ibid). BSTI has right to adopt International Standards (ISO, IEC, Codex etc.) as Bangladesh Standards. 'Till now 150 international standards have been adopted as Bangladesh Standards. Standards Wing of BSTI is being assisted by 6(six) Divisional Committee and 70 Sectional/Technical Committees. 17-sectional committees under Agricultural and Food Divisional Committee are working for Food Standards. The members of the committee include representatives from stakeholder Ministries and departments, universities/research organizations, CAB, Business and trade associations/chambers etc.There is no coordinating mechanism among the laboratories in terms of research and routine test methods' (ibid). In regard to accreditation body a draft act has been prepared and sent to different ministries for comments (ibid).

\subsection{Conformity Assessment Mechanism}

There are about 25 (excluding the branches) food laboratories under various government, autonomous and international organizations in Bangladesh. However, very few are operating down to the regional and district level (ibid).

The following Laboratories are responsible for qualitative and quantitative assessment offood items- 
'Public Health Laboratory of the Institute of Public Health, Dhaka under the MOHFW, Laboratory of the Institute of Public Health Nutrition under the MOHFW,Bangladesh Standard Testing Institution (BSTI) under the Ministry of Industries,Food Testing Laboratory, Directorate of Food under the Ministry of Food and DisasterManagement, Institute of Food Science Technology, Dhaka,Food Testing Laboratory of Dhaka City Corporation under the MOLGRD, Laboratory of Plant Protection Wing of DAE of Ministry of Agriculture,Quality Control Laboratories for frozen fish at Khulna and Chittagong under the Ministry of Fisheries and Livestock-under this Ministry, there is also lab at Fisheries Research Institute at Mymensingh, Laboratory of Department of Livestock under the Ministry of Fisheries and Livestock,Institute of Food Radiation Biology, Atomic Energy Commission under the Ministry of Energy and Mineral Resources, Institute of Nutrition and Food Science, University of Dhaka under the Ministry of Education, Central laboratory and Lab of Post-Harvest Technology of Bangladesh Agricultural Research Institute and Laboratory of Bangladesh Rice Research Institute under the Ministry ofAgriculture,Armed Forces Food and Drug Testing Laboratory, Dhaka Cantonment, Dhaka under theMinistry of Defence,Laboratories of Department of Food Technology and Rural Industry, Department of Dairy Science and Department of Biochemistry of Bangladesh Agricultural University,Chemical Examination Laboratory of CID under the Ministry of Home Affairs, Environment Laboratory, Directorate of Environment under the Ministry Environment and Forests' (Tiwari, n.d.).

\subsection{Government Efforts towards Establishing Food Safety}

To establish food safety, Bangladesh government adopted certain measures. Cabinet of Bangladesh government approved the Safe Food Act, 2013 to co-ordinate more than 15 laws and number of ministries, departments and agencies responsible for food safety. Government took efforts in building policy linkages, public-private sector interaction and human resource / lab infrastructure development, adoption of international standards, strengthening the information, surveillance and alert service, working with SAARC for harmonization of standards on food products etc (FAO/WHO, 2004). Consumer Protection Act, 2009 has been passed by government. Some draft Acts such as, 'Feed Act'; 'Animal Quarantine Act' and 'Animal Disease Control Act' are also awaiting approval (ibid). However, the reflections of government's efforts still are not very satisfactory. The violations are on-going despite all the efforts.

\subsection{NGOs Working in Bangladesh towards Establishing Food Safety}

In Bangladesh, some NGO's are working to establish food security. Consumers Association of Bangladesh (CAB), Bangladesh Paribesh Andolon, Dosher Bangladesh are significant among them. These NGO's are undertaking wide range of activities in order to create awareness among consumers regarding consumer rights, importance of hygiene to ensure food safety for all (ibid). CAB frequently goes to sites to check whether foods are adulterated or not and invites aggrieved consumers to submit complaint to them.

\subsection{The Dilemma on the Issue of Approaching 'Right to Food' by Developing Countries such as Bangladesh}

State Parties are obliged to take steps to achieve progressively the full realization of the right to food by all appropriate means, including particularly adoption of legislative measures. The qualification "within its available resources" refers to those available resources within a State as well as resources available from the international community. While acknowledging that the right to food should be realized progressively, General Comment 12 points out that as minimum core obligations, every State is obliged to ensure for everyone under its jurisdiction access to the minimum essential food which is sufficient, nutritionally adequate and safe, to ensure their freedom from hunger. Thus, a State where a significant number of individuals are deprived of essential foodstuffs is prima facie violating the Covenant (Ahluwalia, 2004).

The right to food imposes the obligations to respect, to protect and to fulfill (which incorporates both an obligation to facilitate and to provide) on State Parties (ibid). These obligations require ultimate fulfillment of dietary needs of people by taking positive steps by government to ensure free, safe, hygienic and sufficient food for every person. This does not mean that government will feed everyone, rather it means that government must create enabling environment so that people can be able to feed themselves by free, safe, hygienic and sufficient food.The State's third obligation to "fulfill" the right to food also entails that under ICESCR Article 11(2), the state shall take steps to "improve measures of production, conservation and distribution of food."

Furthermore, according to General Comment 12 the obligation to "provide" means that in case of inability of a person or group of person for reasons beyond their control to exercise the right to adequate food at their own disposal, States have the obligation to fulfill (provide) the right tofood directly (ibid). It means that if people cannot afford to get food free from adulteration, State has direct responsibility to provide them safe food.

Guideline 13 of the Maastricht Guidelines provides that a distinction must be drawn between the State's "inability" to comply with a legal duty and the "unwillingness" to do so. The burden of proof for demonstrating 
good faith is upon the State. Further, Guideline 15 states that there are positive obligations incumbent upon the State to pro-actively involve itself. Failing to take these indispensable measures is characterized as the acts of violation of the legal obligations emerging from recognition of the ESC rights. Point (c) equates violation of the ESC rights with the omission by a State to enforce laws and to implement policies geared towards the enjoyment of the ESC rights. The formulation and implementation of national strategies for the right to food require full compliance with the principles of accountability, transparency, people's participation, decentralization, legislative capacity and the independence of the judiciary which are key-elements of good governance. Thus, the government's inaction or neglect in securing implementation of the right to food amounts to denial of the right enshrined under Article 11 of ICESCR (ibid).

\section{Challenges to Combat Adulterated Foods in Bangladesh}

By studying in depth on the adulterated foods in Bangladesh, many challenges are identified which are summarized below:

1. Lack of sustained and appropriate implementation by credible authority (Ahmed, 2013).

2. Ill-mentality of gaining super profits at any cost (Rasul, 2013).

3. Only 8 countries among 160 partiesof the International Covenant on Economic, Social and Cultural Rights ratified the Optional Protocol to the ICESCR and Bangladesh is not one of them (Wikipedia, 2013). Moreover 'Right to food' is not fundamental right in Bangladesh.

4. Lack of integration between the Bangladesh Pure Food (Amendment) Act 2005 and BSTI law results in punishment of manufacturers and retailersfor products certified by the BSTI which creates conflict and confusion regarding role and power of the stake-holders (The Daily Star, 2013).

5. The use of pesticides i.e. DDTs though are banned but actually these are still going on.

6. Poor planning of the authorities.

7. Compromising attitude of consumers.

8. Unorganized food control activities and scanty information on food contamination.

9. Food laws and regulations do not embody recent development/ recommendations by Codex, SPS and TBT Agreements.

10. Weak coordination among activities like plant quarantine, food control, standards, enforcement andlabs.

11. Weak Consumer/public awareness programs.

12. Compliance high-cost.

13. Financial resource constraints.

14. Lack of Technology Improvement Research.

15. Poor knowledge of standards, laws/regulations among the producers and consumers.

16. Weak food inspection and enforcement services.

17. BSTI authority claims that they do not have enough manpower to carry out the job to control food safety in the industry (Islam and Hoque, 2013).

18. Multiplicity of Laws. As a minimum 15 laws (excluding the common law provisions) governthe current legal framework of food safety in Bangladesh, which are expected to be coordinated by the Safe Food Act, 2013. But this Act is only approved by the cabinet, not passed (Ali, 2013).

19. The lack of coordination and overlapping areas of responsibility among the multi-sectoral agencies dealing with food safety is one of the reasons for the failure of whole food safety arrangement in Bangladesh as it results severe complexity which is expected to be coordinated by Bangladesh Food Safety Authority proposed in the approved Safe Food Act, 2013 (ibid).

20. Lack of transparency and accountability.

21. Absence of participatory system of consumers.

22. Political influence and corruption of government officials.

23. Regulatory bodies under the FSRRB are terribly bureaucratic. This unnecessary bureaucracy has ultimately made such an important consumer protection law ineffective (ibid).

24. The administrative enforcement mechanism of Bangladesh is not organized and has not designed inspection strategies and there is no clear method of detecting non-compliance with the regulations (ibid).

25. Only a few laboratories in Bangladesh are well equipped and well maintained. Often they suffer shortages of maintenance budget, inadequacy of technological resources, lack of coordination in procedures or methods of testing (FAO/WHO, 2004).

\section{Proposed Mechanism of Transformation of 'Right To Food' as An Enforceable Right in Bangladesh}

In the Constitution of Bangladesh, 'Right to Food' is guaranteed as a directive principle of State Policy which is un-enforceable in nature. Dividing human rights in the two parts of the constitution-some as 
fundamental rights and others as directive principles of state policy affect the State attitude to address the crisis. Recognizing 'Right to food' as a directive principle or goal in the constitution snatch away the right to claim enforcement by the State as we know, under the doctrine of indivisibility of human rights, all human rights are inter-linked and indivisible and division only frustrates the enforcement of those human rights which are categorized by the state as directive principles of state policy. The 'Doctrine of Indivisibility' has also been confirmed by 1993 Vienna Declaration and Programme of Action. This statement was reiterated in paragraph 121 of the proceedings of 2005 World Summit in New York. Universal Declaration of Human Rights 1948 included both civil and political rights and economic, social and cultural rights basing on the principle that these different rights could only successfully exist in combination. Under the 'Full Belly Thesis', without civil and political rights the public cannot assert their economic, social and cultural rights, in the same way without livelihoods and a working society, the public cannot assert or make use of civil or political rights. Therefore, as Bangladesh adopted UDHR, it must adopt the approach of UDHR in interpreting all human rights as indivisible and should not divide human rights under two parts-fundamental rights and fundamental principles of state policy as these rights need to be implemented simultaneously for the sake of people. Bangladesh government should re-think this matter. Again if it is not possible, there is another way i.e., judicial oversight bodies may interpret 'Right to Life' broadly to include the right to food (Golay and Ozden, n.d.) as the right to life is recognized in the constitution of Bangladesh as a basic right. Whatever mechanism is taken by government, it must consider the right of the people to the safe food on human rights basis and should give enforceability to this right.

\section{Recommendations}

To ameliorate the worsening conditions of adulterated food in Bangladesh, the following recommendations are suggested:

1. Food safety policies and strategies should be adopted in a way to include the development of a coordinated, risk-based food control program that covers the entire food supply chain from farm-to-table. This should be supported by a coherent legal framework, which facilitates the development of risk based food regulations and standards. A further action would be to establish a documentation center containing readily accessible information and data on current food safety issues impacting on Bangladesh (Islam and Hoque, 2013).

2. National food inspection and enforcement services should be strengthened to develop and implement riskbased inspection programmes, enforced by properly trained, resourced and supervised food inspectors and in enhanced number (ibid).

3. Preventive approaches to food safety management must be adopted which requires the development and delivery of enhanced education on how to improve food safety and quality.There should also be enhanced support for consumer associations (ibid).

4. Food analysis capability and capacity must be enhanced through the establishment of well-equipped national laboratories, operated by trained analysts utilizing standard methods which are performed under laboratory quality management arrangements (ibid).

5. Good governance must be established to ensure safe and hygienic food for consumers.

6. Food safety as a culture must be developed.

7. Existing laws with the execution of highest penalty possible must be enforced (Ahmed, 2013).

8. Awareness-building campaign among consumers must be carried on (ibid).

9. Ethical practices among the business community with active involvement of the business leaders must be promoted (ibid).

10. Capacity of public health labs to test food items for adulteration on the spot must be developed (ibid).

11. The consumer rights groups should be more vocal and play active role in developing a mass campaign/movement in the country (ibid).

12. A comprehensive media advocacy plan should be adopted to put forward aneffective movement to raise awareness among the people, policy makers and civil society (BanglaNews24.com, 2013).

13. Government's regulatory functions against these offences must be stepped up on emergency basis (Rasul, 2013).

14. Hard vigilance over these mal-practices should be undertaken (ibid).

15. Government must make the National Food Security Council effective in order to enforce law against adulterers (Daily Sun, 2013).

16. A joint effort need to be taken by the ministries of agriculture, food, commerce and LGRD, cabinet division and drug administration to check adulteration of food during Ramadan (ibid).

17. Fair price of farmers should be guaranteed to stop their unethical practices (IRIN, 2013).

18. Harmonization of provisions/standards in various laws/rules is necessary (FAO/WHO, 2004). 
19. Appropriate laws should be adopted and implemented effectively and obstacles in its way should be removed as far as possible.

20. Proper training containing manuals, materials and practical demonstration should be arranged for farmers, food processors, government regulators, policy-makers, vendors and other persons involved in the system for compliance (ibid).

21. Researches in sorting out proper food safety policy and mechanisms in the fields of production, processing, marketing and consumption should be launched (ibid).

22. National parliaments should be encouraged to work towards the adoption of framework laws that establish a participatory mechanism aimed at the adoption of a national strategy for the realization of the right to food (Schutter, 2010).

23. The institutions that are set up as part of a national strategy for the realization of the right to food should be sufficiently well resourced (ibid).

24. Victims must have access to an independent judiciary or other complaints mechanisms to complain about violations of the right to food (ibid).

\section{Conclusion}

Fulfilling the right to food is the fundamental responsibility of governments as NGOs declared during the World Food Summit in 1996. 'Food security is a human right which must take precedence over macroeconomic and trade concerns, militarism and the dictates of the marketplace. That achieving food security for all demands the "full engagement of all stakeholders" such as civil society, governments, international organizations and multilateral institutions' (Ahluwalia, 2004). To ensure an active and sound health essential for development of individuals as well as national life at large, there is no substitute of healthy food and healthy environment. So undoubtedly this issue is the top priority issue to be addressed as properly and promptly as possible. From the research, we found that this right to food has not been effectively operationalized in Bangladesh. Though Bangladesh is a party to the International Covenant (ICESCR) and the CRC and Bangladesh government has formulated many schemes and policies to ensure food and nutrition security, the reality is that still there exists a wide gap between the rhetoric and reality (ibid). As food adulteration reached a dangerous proportion in the country (Zee Media Corporation Limited, 2013), it is more than high time for a truly dedicated and long-lasting drive against these evil doings with the intention of protecting consumers from the harmful in-take and it's all adverse effects (Rasul, 2013). Government and stake-holders should address the problem from a new angle on top priority basis Bona Fide, then only all the initiatives adopted by them can be expected to be meaningful.

[1] Wikipedia, Adulterated food: Poisonous or deleterious substances, September 2013, Available at: <http://en.wikipedia.org/wiki/Adulterated_food> Accessed on 28 September 2013.

[2] Wikipedia, Adulterated food: Economic adulteration, September 2013, Available at: <http://en.wikipedia.org/wiki/Adulterated_food> Accessed on 28 September 2013.

[3] Golay, C. and Ozden M., The Right to Food, Part of a series of the Human Rights Programmeof the Europe-Third World Centre (CETIM) Annex 2: list of states parties to the international covenant on economic, social and cultural rights (ratification by 151 States), p. 19, 23, 35, 43 .

[4] Bangladesh: Constitution of the People's Republic of Bangladesh, 1972, Article 15

[5] Wikipedia., Right to food: Adoption around the World: Implicit or as directive principle, 10 June 2013, Available at: <http://en.wikipedia.org/wiki/Right to food> Accessed on 28 September 2013.

[6] Tiwari, G.M., Laws and Regulation to Foods and Food Additives. Country Report: Bangladesh: Introduction to Regulatory Framework for Foods: Administrative Authorities (n.d.), p.2, 3, 4, 8,10, 11.

[7] Ali, A.N. M. A., Food safety and public health issues in Bangladesh: a regulatory (2013) 8 (1) European Food and Feed Law Review 31-40, p.2, 3, 4,8, 9, 11, 12, 13-19, Available at:<http://ro.uow.edu.au/lhapapers/156> Accessed on 10 November 2013.

[8] Ahmed, R. (Ed.) Ensuring punishment for food adulteration, The News Today, 2013, Available at: <http://www.newstoday.com.bd/index.php?option=details\&news_id=2351483\&date=2013-07-21> Accessed on 28 September 2013 .

[9] Alam, M. (Ed.) Seminar on Safe Food Act-2013, The Independent, 3 June2013, Available at: <http://www.theindependentbd.com/index.php?option=com_content\&view=article\&id=172171:seminar-on-safe-food-act2013\&catid=136:metropolitan-others\&Itemid=175>Accessed on 12 October 2013.

[10] Rasul, E. (Asso. Ed.). Adulterated foods posing health hazards.The Independent.24 July 2013, Available at: $<$ http://www.theindependentbd.com/index.php?option=com_content\&view=article\&id=179060:adulterated-foods-posing-healthhazards\&catid=139:editorial-post-editorial\&Itemid=136>Accessed on 28 September 2013

[11] Rahman, M. S., Food adulteration, a dire situation, The New Nation, 28 September, 2013. Available at: <http://thenewnationbd.com/newsdetails.aspx?newsid=45705> Accessed on 28 September 2013

[12] Faruque, O., Adulteration in Food in Bangladesh needs immediate effective measures. ProbashiBarta, 28 June, 2013. Available at: <http://www.pbc24.com/index.php/article-posts/article-details?article_id=966>Accessed on 28 September 2013

[13] FAO/WHO, Regional Conference on Food Safety for Asia and Pacific: Bangladesh Country Paper, Seremban, Malaysia, 24-27 May 2004, p.4,5, 6, 8, 9, 10-13.

[14] Ahmed, S. M., Adulterated food: a serious public health problem in Bangladesh, 10 October 2012, Available at: <http://syedmasudahmed.blogspot.com/2012/10/adulterated-food-serious-public-health.html> Accessed on 28 September 2013. 
[15] Ahmed, S. F. (Ed.), Bangladesh food adulteration killing silently. Natun Barta.com, 16 August 2013, Available at: <http://www.natunbarta.com/english/health/2013/08/16/7883> Accessed on 28 September 2013.

[16] The Daily Star, Food Adulteration Complainant to get 25pc of fine, The Daily Star, 1 October, 2013, Available at: <http://www.thedailystar.net/beta2/news/complainant-to-get-25pc-of-fine/> Accessed on 12 October 2013.

[17] Hossain, M.,Food Safety and Quality Control in Bangladesh, 10 September, 2008, Available at: <http://www.thefinancialexpressbd.com/2008/09/10/45060.html> Accessed on 12 October 2013.

[18] The Daily Star, Food safety law with some teeth: Stringent enforcement key to success. The Daily Star, 3 July, 2013. Available at: <http://www.thedailystar.net/beta2/news/food-safety-law-with-some-teeth/> Accessed on 12 October 2013.

[19] Law Commission Bangladesh, A report regarding a proposed amendment of certain sections of the Bangladesh Pure Food Ordinance, 1959 (Ordinance No. LXVIII of 1959), p.1, Available at: www.lawcommissionbangladesh.org/reports/80.doc Accessed on 28 September 2013.

[20] The Daily Ittefaq. Adulteration and the Safe Food Act, The Daily Ittefaq, 5 July, 2013, Available at: < http://www.clickittefaq.com/editorial-oped/adulteration-and-the-safe-food-act/> Accessed on 12 October 2013.

[21] Ahluwalia, P., The implementation of the right to food at the national level: A critical examination of the Indian campaign on the right to food as an effective operationalization of Article 11 of ICESCR, 2004, Center for human rights and global justice. Economic, social and cultural rights series Number 8, p.11, 14, 15, 16, 17, 18, 19, 27, 48, 51.

[22] Wikipedia. Right to food: Adoption around the World: Commitment via ICESCR, 10 June 2013, Available at: <http://en.wikipedia.org/wiki/Right_to_food> Accessed on 28 September 2013.

[23] The Daily Star, Food Act, BSTI law lack integration, The Daily Star,7 November, 2012, Available at: <http://archive.thedailystar.net/newDesign/news-details.php?nid=256561> Accessed on 12 October 2013.

[24] Islam, G.M.R. and Hoque, M.M., Food safety regulation in Bangladesh, chemical hazard and some perception to overcome the dilemma:Present status of rules and regulation related to food safety in Bangladesh, International Food Research Journal 20(1): 2013, 48-49, 56, Available at:<//www.ifrj.upm.edu.my>Accessed on 9 November 2013.

[25] BanglaNews24.com, Movement against food adulteration urgent, BanglaNews24.com, 4 Sep 2013, Available at: <http://banglanews24.com/English/detailsnews.php?nssl=87511763ad4f9a0df533c9678ad3ae53\&nttl=0409201376670> Accessed on 28 September 2013

[26] Daily Sun, Food adulteration a 'silent killer' in Bangladesh, Daily Sun, July 18, 2012, Available at: http://www.dailysun.com/index.php?view=details\&archiev=yes\&arch_date=18-07-2012\&type=Food-adulteration-a$\% \mathrm{C} 3 \% \mathrm{~A} 2 \% \mathrm{E} 2 \% 82 \% \mathrm{AC} \% \mathrm{CB} \% 9 \mathrm{Csilent-killer} \% \mathrm{C} 3 \% \mathrm{~A} 2 \% \mathrm{E} 2 \% 82 \% \mathrm{AC} \% \mathrm{E} 2 \% 84 \% \mathrm{~A} 2$-in-

Bangladesh\&pub_no=207\&cat_id=1\&menu_id=2\&news_type_id=1\&index=0, Accessed on 28 September 2013.

[27] IRIN, Analysis: Why food can kill in Bangladesh: Government efforts, 2013, Available at: <http://www.irinnews.org/printreport.aspx?reportid=97824> Accessed on 12 October2013.

[28] Schutter, O. D., United Nations Special Rapporteur on the Right To Food,Briefing note on 'Countries tackling hunger with aRight to food approach: Significant progress in implementing the right to food at national Scale in Africa, Latin America and South Asia, 1 May 2010, p.1, 9, 13, 14 .

[29] Zee Media Corporation Limited. Bangladesh approves tougher law to fight food adulteration, 1 July 2013, Available at: <http://zeenews.india.com/news/south-asia/bangladesh-approves-tougher-law-to-fight-food-adulteration_859173.html> Accessed on 28 September 2013. 